\title{
High incidence of asymptomatic SARS-CoV-2 infection, Chongqing, China
}

Yang Tao ${ }^{1,2 \#}$, Panke Cheng ${ }^{3,4 \#}$, Wen Chen ${ }^{5 \#}$, Peng Wan ${ }^{1}$, Yaokai Chen ${ }^{2}$, Guodan Yuan ${ }^{2}$, Junjie $\mathrm{Chen}^{6}$, Da Huo ${ }^{6}$, Ge Guan ${ }^{6}$, Dayu Sun ${ }^{6}, \mathrm{Ju}_{\text {Tan }}^{6}$, Guanyuan Yang ${ }^{6}$, Wen Zeng ${ }^{6 *}$, Chuhong $\mathrm{Zhu}^{6,7 *}$

${ }^{1}$ Beibei Tranditional Chinese Medical Hospital, Chongqing, 400000, China

${ }^{2}$ Chongqing Public Health Medical Center, Chongqing, 400000, China

${ }^{3}$ Clinical Immunology Translational Medicine Key Laboratory of Sichuan Province, Sichuan Provincial People's Hospital, University of Electronic Science and Technology of China, Chengdu 611731, China

${ }^{4}$ Chinese Academy of Sciences Sichuan Translational Medicine Research Hospital, Chengdu 610072, China

${ }^{5}$ The 8th Medical Center of Chinese PLA General Hospital, Beijing 100091, China

${ }^{6}$ Department of Anatomy, National and Regional Engineering Laboratory of Tissue Engineering, State and Local Joint Engineering Laboratory for Vascular Implants, Key Lab for Biomechanics and Tissue Engineering of Chongqing, Army Medical University (Third Military Medical University), Chongqing 400038, China

${ }^{7}$ State Key Laboratory of Trauma, Burn and Combined injury; Department of Plastic and Aesthetic Surgery, Southwest Hospital; Army Medical University (Third Military Medical University), Chongqing 400038, China.

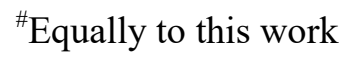

*Corresponding author: Chuhong Zhu, Department of Anatomy, Third Military

Medical University, Chongqing, 400038, China. E-mail: zhuch99@tmmu.edu.cn. Fax: 86-23

68772189. Or Wen Zeng, Department of Anatomy, Third Military Medical University, Chongqing, 400038, China. Email: zengw0105@163.com Fax: 86-23 68771290. 
medRxiv preprint doi: https://doi.org/10.1101/2020.03.16.20037259; this version posted March 23, 2020. The copyright holder for this

preprint (which was not certified by peer review) is the author/funder, who has granted medRxiv a license to display the preprint in

It is made available under a CC-BY-NC-ND 4.0 International license .

\section{Summary}

Background SARS-CoV-2 has been a global pandemic, but the emergence of asymptomatic patients has caused difficulties in the prevention of the epidemic. Therefore, it is significant to understand the epidemiological characteristics of asymptomatic patients with SARS-CoV-2 infection.

Methods In this single-center, retrospective and observational study, we collected data from 167 patients with SARS-CoV-2 infection treated in Chongqing Public Health Medical Center (Chongqing, China) from January to March 2020. The epidemiological characteristics and variable of these patients were collected and analyzed.

Findings $82.04 \%$ of the SARS-CoV-2 infected patients had a travel history in Wuhan or a history of contact with returnees from Wuhan, showing typical characteristics of imported cases, and the proportion of severe Covid-19 patients was $13.2 \%$, of which $59 \%$ were imported from Wuhan. For the patients who was returnees from Wuhan, 18.1\% was asymptomatic patients. In different infection periods, compared with the proportion after $1 / 31 / 2020$, the proportion of asymptomatic patient among SARS-CoV-2 infected patient was higher(19\% VS 1.5\%). In different age groups, the proportion of asymptomatic patient was the highest(28.6\%) in children group under 14, next in elder group over 70 (27.3\%). Compared with mild and common Covid-19 patients, the mean latency of asymptomatic was longer (11.25 days VS 8.86 days), but the hospital length of stay was shorter (14.3 days VS 16.96 days) .

Conclusion The SARS-CoV-2 prevention needs to focus on the screening of asymptomatic patients in the community with a history of contact with the imported population, especially for children and the elderly population.

Keywords: SARS-CoV-2; Covid-19; asymptomatic patients; imported population 


\section{Introduction}

WHO has announced on March 11 in Switzerland that SARS-CoV-2 has the characteristics of a global pandemic ${ }^{1}$. As of March 15, 2020, China has accumulated 81,048 cases of SARS-CoV-2 infection and a mortality rate of $3.95 \%$, also, there is a total of 64322 cases expect China, with a mortality rate of $3.51 \%{ }^{1,2}$. The proportion of asymptomatic patients has gradually increased ${ }^{3}$. Asymptomatic patients are still highly contagious, paying special attention to the epidemiological characteristics of asymptomatic patients is of great significance for the control of the epidemic.

Wuhan, Hubei was the first outbreak location in China ${ }^{4}$. Chongqing is a province adjacent to Hubei, as of March 15, had 576 cases of SARS-CoV-2 infection, and a mortality rate of $1.04 \%{ }^{5}$. However, the epidemiological characteristics of SARS$\mathrm{CoV}-2$ infected patients in the input area are not clear at present, especially for the asymptomatic patients. This article takes Chongqing, China, as a representative area of importation case, analyzes the case data of SARS-CoV-2 infected patients, especially for the asymptomatic patients, to provide clinical reference for the prevention of SARSCoV-2 infection.

\section{Materials and Methods}

Patients The clinical data of 167 SARS-CoV-2 infected patients treated in Chongqing Public Health Medical Center from January 2020 to March 2020 were collected. COVID-19 is diagnosed according to the WHO Interim Guidelines ${ }^{6}$. The severity of COVID -19 was defined according to the American Thoracic Society's Community Acquired Pneumonia Guidelines ${ }^{7}$. A confirmed case of SARS-CoV-2 infection was defined as a positive result on RT-PCR assay of nasal and pharyngeal swab specimens. This study was approved by the Ethics Committee of Chongqing Public Health Medical Treatment Center (NO.2020-018-01-KY), informed consent was allowed to be waived.

Data collection We reviewed and analyzed the clinical files, radiologic and laboratory results of all 167 patients. All data are completed through independent survey forms to ensure that they do not interfere with each other. At the same time, 
three investigators complete the data collection and management to ensure the independence, completeness and authenticity of the data.

Radiologic and laboratory detection The detection of SARS-CoV-2 was determined based on new coronavirus pneumonia diagnosis and treatment plan developed by the National Health Committee of the People's Republic of China. All the patients performed the RT-PCR assay of nasal and pharyngeal swab specimens for SARS-CoV-2 detection ${ }^{8}$. Radiologic and laboratory detection of all patients were completed according to normal inspection procedures.

Statistical Analysis Data in the full text are expressed as median, mean $\pm \mathrm{SD}$, or percentage. The missing data are not counted. Statistical analysis in this study were conducted with SPSS 25.0.

\section{Results}

\section{Epidemiological characteristics of SARS-CoV-2 infected patients in Chongqing}

There were 22 patients with severe COVID-19, and the proportion of severe COVID-19 in Recently visited Wuhan was highest (24.1\%), accounting for 59\% of the total number of severe Covid-19. 20 asymptomatic patients with SARS-CoV-2 infection, 2 cases $(3.7 \%)$ of the returnees from Wuhan; and the highest proportion (15 cases, $18.1 \%$ ) of those who had contacted with returnees from Wuhan, accounting for $75 \%$ of the total number of asymptomatic patients. The median age of 167 SARS-CoV2 infected patients was 46 years old, COVID-19 patients was 55 years old, and asymptomatic patients was 47 years old. Overall, the proportion of severe COVID-19 was $13.2 \% ; 36.4 \%$ of the SARS-CoV-2 infected patients over 70 years old was severe COVID-19 patients. It is worth noting that $28.6 \%$ of them who were infected with SARS-CoV-2 in children were asymptomatic patients, and $27.3 \%$ of them who were over 70 years old, suggesting that the population of children and elder may be the main population with asymptomatic infection. Before $1 / 31 / 2020$, the proportion of severe COVID-19 was significantly higher than the later $(17.9 \%$ vs. 10\%). However, the proportion of asymptomatic patients after 1/31/2020 was significantly higher than before (19\% vs. 1.5\%). Due to the closure of Wuhan, Hubei Province on January 
medRxiv preprint doi: https://doi.org/10.1101/2020.03.16.20037259; this version posted March 23, 2020. The copyright holder for this preprint (which was not certified by peer review) is the author/funder, who has granted medRxiv a license to display the preprint in It is made available under a CC-BY-NC-ND 4.0 International license .

23,2020, indicating that a large number of asymptomatic patients may not be directly imported cases. As shown in Table 1.

Table.1 Epidemiological characteristics of SARS-CoV-2 infected patients

\begin{tabular}{|c|c|c|c|c|c|c|c|c|c|}
\hline & \multicolumn{2}{|c|}{$\begin{array}{l}\text { Recently visited } \\
\text { Wuhan }\end{array}$} & \multicolumn{2}{|c|}{$\begin{array}{l}\text { Had contacted with } \\
\text { returnees from Wuhan }\end{array}$} & \multicolumn{2}{|c|}{$\begin{array}{c}\text { No previous } \\
\text { contact history* }\end{array}$} & & $\begin{array}{l}\text { Before } \\
\text { /31/2020 }\end{array}$ & $\begin{array}{c}\text { After } \\
2 / 1 / 2020\end{array}$ \\
\hline All patients & \multicolumn{2}{|c|}{$54(32.3 \%)$} & \multicolumn{2}{|r|}{$83(49.7 \%)$} & \multicolumn{2}{|c|}{$30(18.0 \%)$} & & $7(40.1 \%)$ & $100(59.9 \%)$ \\
\hline Severe patients & \multicolumn{2}{|c|}{$13(24.1 \%)$} & \multicolumn{2}{|r|}{$7(8.4 \%)$} & \multicolumn{2}{|c|}{$2(6.7 \%)$} & & $2(17.9 \%)$ & $10(10 \%)$ \\
\hline \multirow[t]{2}{*}{ Asymptomatic patients } & \multicolumn{2}{|c|}{$2(3.7 \%)$} & & $15(18.1 \%)$ & \multicolumn{2}{|c|}{$3(10 \%)$} & & $1(1.5 \%)$ & $19(19 \%)$ \\
\hline & $0-14$ & 15 & & 30-39 & $40-49$ & $50-$ & & $60-69$ & $\geq 70$ \\
\hline All patients & $7(4.2 \%)$ & $21(12$ & $5 \%)$ & $37(22.2 \%)$ & $39(23.4 \%)$ & $36(21$ & & $16(9.6 \%)$ & $11(6.6 \%)$ \\
\hline Severe patients & & & & $7(18.9 \%)$ & $3(7.7 \%)$ & $5(13$. & & $3(18.8 \%)$ & $4(36.4 \%)$ \\
\hline Asymptomatic patients & $2(28.6 \%)$ & $2(9$. & & $2(5.4 \%)$ & $6(15.4 \%)$ & $5(13$. & & 0 & $3(27.3 \%)$ \\
\hline
\end{tabular}

Data are $\mathrm{n}(\%)$, unless otherwise specified. SARS-CoV-2=severe acute respiratory syndrome coronavirus 2.

Patients who have confirmed SARS-CoV-2 infection or are highly suspected of being infected. *Patients who had not recently visited Wuhan or contacted with returnees from Wuhan Median Age $=46 ; \quad$ Severe Patients' Median Age $=55 ; \quad$ Asymptomatic Patients' Median Age $=47$

\section{Clinical characteristics of severe covid-19 in Chongqing}

$59.09 \%$ of severe COVID-19 patients had a history of travel to Wuhan, which was a typical imported case. The median age of 22 severe COVID-19 patients was 55 years old. For the severe COVID-19 patients, the changes of clinical characteristics, radiologic and laboratory indexes were consistent with the previous reports; only 3 (13.64\%) severe patients have comorbidities of liver dysfunction, lower than the previous reports $(25.43 \%)^{9}$. See Table 2 for the detailed data.

Table .2 Variable of severe patients at different ages

\begin{tabular}{|c|c|c|c|c|c|}
\hline & $30-39 \quad(n=7)$ & $40-49(n=3)$ & $50-59(n=5)$ & $60-69(n=3)$ & $\geq 70(n=4)$ \\
\hline All patients before $1 / 31 / 2020$ & $5(71.4 \%)$ & $1(33.3 \%)$ & $3(60 \%)$ & $1(33.3 \%)$ & $2(50 \%)$ \\
\hline Recently visited Wuhan & $5(71.4 \%)$ & $2(66.7 \%)$ & $4(80 \%)$ & 0 & $2(50 \%)$ \\
\hline Contact with Wuhan residents & $2(28.6 \%)$ & $1(33.3 \%)$ & $1(20 \%)$ & $1(33.3 \%)$ & $2(50 \%)$ \\
\hline Mean latency (days) & 9.1 & 8.3 & 12.3 & -- & 10.3 \\
\hline \multicolumn{6}{|l|}{ Clinical symptoms } \\
\hline Fever & $7(100 \%)$ & $2(66.7 \%)$ & $4(80 \%)$ & $1(33.3 \%)$ & $2(50 \%)$ \\
\hline
\end{tabular}


medRxiv preprint doi: https://doi.org/10.1101/2020.03.16.20037259; this version posted March 23, 2020. The copyright holder for this preprint (which was not certified by peer review) is the author/funder, who has granted medRxiv a license to display the preprint in It is made available under a CC-BY-NC-ND 4.0 International license .

\begin{tabular}{|c|c|c|c|c|c|}
\hline Shortness of breath & $1(14.3 \%)$ & $1(33.3 \%)$ & $3(60 \%)$ & $2(66.7 \%)$ & $4(100 \%)$ \\
\hline Fatigue & $4(57.1 \%)$ & 0 & $1(20 \%)$ & $3(100 \%)$ & $2(50 \%)$ \\
\hline \multicolumn{6}{|l|}{ Comorbidities } \\
\hline ARDS & 0 & 0 & 0 & 0 & 0 \\
\hline Acute kidney injury & 0 & 0 & 0 & 0 & 0 \\
\hline Myocardial injury & 0 & 0 & 0 & 0 & 0 \\
\hline Liver dysfunction & $1(14.3 \%)$ & 0 & $1(20 \%)$ & 0 & $1(25 \%)$ \\
\hline Urinary infection & 0 & 0 & 0 & 0 & 0 \\
\hline Digestive system damage & 0 & 0 & 0 & 0 & 0 \\
\hline \multicolumn{6}{|l|}{ Abnormalities on chest $\mathrm{CT}$} \\
\hline Ground-glass opacity & $6(85.7 \%)$ & $1(33.3 \%)$ & $2(40 \%)$ & 0 & $2(50 \%)$ \\
\hline Bilateral patchy shadowing & $3(42.9 \%)$ & $2(66.7 \%)$ & $1(33.3 \%)$ & 0 & $1(25 \%)$ \\
\hline No obvious abnormalities & 0 & 0 & 0 & 0 & 0 \\
\hline \multicolumn{6}{|l|}{ Laboratory findings } \\
\hline White-cell count Median (IQR) & $5.29(4.1-8.2)$ & $3.3(3.26-3.34)$ & $5.17(3.2-6.07)$ & $6.34(5.43-6.68)$ & $3.05(2.25-3.85)$ \\
\hline Neutrophil Percentage median(IQR) & $\begin{array}{c}60.3 \% \\
(57.7-75.6 \%)\end{array}$ & $\begin{array}{c}60.7 \% \\
(58-77.5 \%)\end{array}$ & $\begin{array}{c}72.3 \% \\
(63.9-75.1 \%)\end{array}$ & $\begin{array}{c}82.7 \% \\
(70.9-87.1 \%)\end{array}$ & $\begin{array}{c}69.8 \% \\
(64.2-77.6 \%)\end{array}$ \\
\hline Lymphocyte count Median (IQR) & $2.19(0.67-2.97)$ & $0.855(0.75-0.96)$ & $0.78(0.75-1.07)$ & $0.69(0.63-1.43)$ & $0.5(0.4-0.97)$ \\
\hline \multicolumn{6}{|l|}{$\mathrm{T}$ cell detection } \\
\hline $\mathrm{CD} 4+\mathrm{T}$ cell count & $399(85-881)$ & 393(301-1083) & $167(104-226)$ & $117(101-356)$ & $176(159-230)$ \\
\hline $\mathrm{CD} 8+\mathrm{T}$ cell count & $342(62-692)$ & $304(151-812)$ & $235(154-316)$ & $121(74-404)$ & $111(96-141)$ \\
\hline $\mathrm{CD} 4+/ \mathrm{CD} 8+$ & $1.18(0.66-1.64)$ & $1.33(1.29-1.99)$ & $0.69(0.67-0.71)$ & $0.88(0.83-1.59)$ & $1.44(1.25-2.41)$ \\
\hline Platelet count, Median (IQR) & $205.5(133-503)$ & $186(174-233)$ & $77(68-86)$ & $158(131-356)$ & $130.5(121-140)$ \\
\hline $\begin{array}{l}\text { Elevated C-reactive protein } \\
\qquad(>10 \mathrm{mg} / \mathrm{L})\end{array}$ & $3(42.9 \%)$ & $1(33.3 \%)$ & $1(20 \%)$ & $2(66.7 \%)$ & $4(100 \%)$ \\
\hline Elevated Procalcitonin $(>0.5 \mathrm{ng} / \mathrm{ml})$ & $3(42.9 \%)$ & $1(33.3 \%)$ & $2(20 \%)$ & $1(33.3 \%)$ & $3(75 \%)$ \\
\hline \multicolumn{6}{|l|}{ Clinical outcome } \\
\hline Recovery & $7(100 \%)$ & $3(100 \%)$ & $5(100 \%)$ & $3(100 \%)$ & $4(100 \%)$ \\
\hline Hospital length of stay (days) & 18.3 & 17 & 26.5 & 15.7 & 21.25 \\
\hline Death & 0 & 0 & 0 & 0 & 0 \\
\hline
\end{tabular}

Data are median (IQR), n (\%) or mean (SD). Some patients lack certain tests, or some patients' mean latency is unknown. White blood cell count $\left(\times 10^{9}\right.$ cells per L). Lymphocyte count $\left(\times 10^{9}\right.$ cells per L). Platelet count, $\times 10^{9}$ per L. ARDS=acute respiratory distress syndrome. Patients means people who have confirmed SARS-CoV-2 infection or are highly suspected of being infected.

\section{Clinical characteristics of asymptomatic patients in Chongqing}

For the asymptomatic patients, compared with mild and common Covid-19 patients, the mean latency of 50-59 age group ( 7 days vs. 9.6 days) and children group ( 9 days vs. 11.7 days) were shorter, and other age group was significantly longer, especially in the 30-39 age group (20.5 days vs. 7.2 days), existence C-reactive protein ( 3 cases, $15 \%$ 
medRxiv preprint doi: https://doi.org/10.1101/2020.03.16.20037259; this version posted March 23, 2020. The copyright holder for this preprint (which was not certified by peer review) is the author/funder, who has granted medRxiv a license to display the preprint in It is made available under a CC-BY-NC-ND 4.0 International license.

vs. 33 cases, 26.4\%) and procalcitonin ( 2 cases, $10 \%$ vs. 11 cases, $8.8 \%$ ) increase. Most of the asymptomatic patients did not show typical and abnormal clinical characteristics, radiologic and laboratory indexes, only $1(5 \%)$ had myocardial injury. In particular, some of the asymptomatic patients also had atypical changes in the radiologic indexes, which were not the diagnostic criterion of Covid-19, such as bronchiectasis, general inflammatory changes in the lung, etc. For the asymptomatic patients over the age of 70 , there were $2(66.67 \%)$ patients with ground-glass opacity in radiologic examination. All the SARS-CoV-2 infected patients were treated according to the new coronavirus pneumonia diagnosis and treatment plan developed by the National Health Committee of the People's Republic of China. At present, all the patients have recovered. For the asymptomatic patients, compared with the mild and common Covid-19 patient, the hospital length of stay in children group was prolonged (16.5 days vs 9.8 days). See Table 3 and Table S1 for the detailed data.

Table .3 Variable of asymptomatic patients at different ages

\begin{tabular}{|c|c|c|c|c|c|c|}
\hline & $0-14(n=2)$ & $15-29(n=2)$ & $30-39(n=2)$ & $40-49(n=6)$ & $50-59(n=5)$ & $\geq 70(n=3)$ \\
\hline $\begin{array}{l}\text { All patients before } \\
\qquad 2020.1 .31\end{array}$ & 0 & 0 & 0 & 0 & $1(20 \%)$ & 0 \\
\hline \multicolumn{7}{|l|}{ Exposure history } \\
\hline $\begin{array}{l}\text { Recently visited } \\
\text { Wuhan }\end{array}$ & 0 & $1(50 \%)$ & $1(50 \%)$ & 0 & 0 & 0 \\
\hline $\begin{array}{c}\text { Contact with Wuhan } \\
\text { residents }\end{array}$ & $2(100 \%)$ & $1(50 \%)$ & 0 & $4(66.7 \%)$ & $4(80 \%)$ & $3(100 \%)$ \\
\hline Smoking history & 0 & 0 & $1(50 \%)$ & $2(33.3 \%)$ & $2(40 \%)$ & 0 \\
\hline Mean latency (day) & 9 & 8.5 & 20.5 & 8.8 & 7 & 13.7 \\
\hline \multicolumn{7}{|l|}{ Comorbidities } \\
\hline ARDS & 0 & 0 & 0 & 0 & 0 & 0 \\
\hline Acute kidney injury & 0 & 0 & 0 & 0 & 0 & 0 \\
\hline Myocardial injury & 0 & 0 & 0 & $1(16.7 \%)$ & 0 & 0 \\
\hline Liver dysfunction & 0 & 0 & 0 & 0 & 0 & 0 \\
\hline Urinary tract infection & 0 & 0 & 0 & 0 & 0 & 0 \\
\hline $\begin{array}{c}\text { Digestive system } \\
\text { damage }\end{array}$ & 0 & 0 & 0 & 0 & 0 & 0 \\
\hline \multicolumn{7}{|c|}{ Abnormalities on chest $\mathrm{CT}$} \\
\hline Ground-glass opacity & 0 & $1(50 \%)$ & $1(50 \%)$ & $1(16.7 \%)$ & $1(20 \%)$ & $2(66.7 \%)$ \\
\hline $\begin{array}{l}\text { Bilateral patchy } \\
\text { shadowing }\end{array}$ & 0 & $1(50 \%)$ & 0 & 0 & $1(20 \%)$ & 0 \\
\hline
\end{tabular}


medRxiv preprint doi: https://doi.org/10.1101/2020.03.16.20037259; this version posted March 23, 2020. The copyright holder for this preprint (which was not certified by peer review) is the author/funder, who has granted medRxiv a license to display the preprint in It is made available under a CC-BY-NC-ND 4.0 International license.

\begin{tabular}{|c|c|c|c|c|c|c|}
\hline $\begin{array}{l}\text { No obvious } \\
\text { abnormalities }\end{array}$ & $2(100 \%)$ & 0 & 0 & $4(66.7 \%)$ & 0 & 0 \\
\hline \multicolumn{7}{|l|}{ Laboratory findings } \\
\hline $\begin{array}{l}\text { White blood cell count } \\
\text { Median (IQR) }\end{array}$ & $\begin{array}{c}4.66 \\
(3.81-5.5)\end{array}$ & 3.9 & $\begin{array}{c}7.105 \\
(5.11-9.1)\end{array}$ & $\begin{array}{c}5.9 \\
(4.11-6.27)\end{array}$ & $\begin{array}{c}6.42 \\
(6.68-9.4)\end{array}$ & $\begin{array}{c}5.19 \\
(5.17-8.05)\end{array}$ \\
\hline $\begin{array}{c}\text { Neutrophil Percentage } \\
\text { median(IQR) }\end{array}$ & -- & $\begin{array}{c}46.8 \% \\
(35.6-58.0 \%)\end{array}$ & $\begin{array}{c}62.15 \% \\
(60.1-64.2 \%)\end{array}$ & $\begin{array}{c}63 \% \\
(41.6-83.2 \%)\end{array}$ & $\begin{array}{c}62.5 \% \\
(60.2-67 \%)\end{array}$ & $\begin{array}{c}69.2 \% \\
(61.4-77.1 \%)\end{array}$ \\
\hline $\begin{array}{l}\text { Lymphocyte count } \\
\text { Median (IQR) }\end{array}$ & $\begin{array}{c}2.925 \\
(1.91-3.94)\end{array}$ & $\begin{array}{c}1.63 \\
(1.21-2.05)\end{array}$ & $\begin{array}{c}2.135 \\
(1.31-2.96)\end{array}$ & $\begin{array}{c}1.3 \\
(0.96-1.99)\end{array}$ & $\begin{array}{c}2.04 \\
(2.03-3)\end{array}$ & $\begin{array}{c}0.83 \\
(0.78-2.57)\end{array}$ \\
\hline \multicolumn{7}{|l|}{$\mathrm{T}$ cell detection } \\
\hline CD4+ T cell count & $\begin{array}{c}811 \\
(768-854)\end{array}$ & 691 & 420 & $\begin{array}{c}433 \\
(211-886)\end{array}$ & $\begin{array}{c}253 \\
(239-1251)\end{array}$ & $\begin{array}{c}273 \\
(188-1033)\end{array}$ \\
\hline CD8+ T cell count & 561 & 537 & -- & $\begin{array}{c}370 \\
(159-516)\end{array}$ & -- & -- \\
\hline CD4+/CD8+ & 1.37 & 1.29 & -- & $\begin{array}{c}1.33 \\
(1.13-2.40)\end{array}$ & -- & -- \\
\hline $\begin{array}{l}\text { Platelet count, Median } \\
\qquad \text { (IQR) }\end{array}$ & $\begin{array}{c}140.5 \\
(30-251)\end{array}$ & 166 & $\begin{array}{c}229 \\
(221-237)\end{array}$ & $\begin{array}{c}183 \\
(87-328)\end{array}$ & $\begin{array}{c}197 \\
(192-198)\end{array}$ & \\
\hline $\begin{array}{l}\text { Elevated C-reactive } \\
\text { protein }(>10 \mathrm{mg} / \mathrm{L})\end{array}$ & 0 & $\begin{array}{c}1 \\
(50 \%)\end{array}$ & 0 & $\begin{array}{c}1 \\
(16.7 \%)\end{array}$ & $\begin{array}{c}1 \\
(20 \%)\end{array}$ & 0 \\
\hline $\begin{array}{l}\text { Elevated Procalcitonin } \\
\qquad(>0.5 \mathrm{ng} / \mathrm{ml})\end{array}$ & $\begin{array}{c}1 \\
(50 \%)\end{array}$ & 0 & 0 & $\begin{array}{c}1 \\
(16.7 \%)\end{array}$ & 0 & 0 \\
\hline \multicolumn{7}{|l|}{ Clinical outcome } \\
\hline Recovery & $2(100 \%)$ & $2(100 \%)$ & $2(100 \%)$ & $6(100 \%)$ & $5(100 \%)$ & $3(100 \%)$ \\
\hline $\begin{array}{l}\text { Hospital length of stay } \\
\qquad \text { (days) }\end{array}$ & $\begin{array}{c}16.5 \\
(14-19)\end{array}$ & $\begin{array}{r}10.5 \\
(8-13)\end{array}$ & $\begin{array}{c}16 \\
(7-25)\end{array}$ & $\begin{array}{c}12.2 \\
(10-15)\end{array}$ & $\begin{array}{r}11.6 \\
(6-15)\end{array}$ & $\begin{array}{c}19 \\
(14-22)\end{array}$ \\
\hline Death & 0 & 0 & 0 & 0 & 0 & 0 \\
\hline
\end{tabular}

Data are median (IQR), n (\%) or mean (SD). Some patients lack certain tests, or some patients' mean latency is unknown. White blood cell count $\left(\times 10^{9}\right.$ cells per L). Lymphocyte count $\left(\times 10^{9}\right.$ cells per L) . Platelet count, $\times 10^{9}$ per L. ARDS=acute respiratory distress syndrome. Patients means people who have confirmed SARS-CoV-2 infection or are highly suspected of being infected.

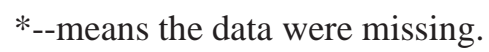

\section{Clinical outcome of SARS-CoV-2 infected patients in Chongqing}

With the extension of the epidemic, the mean latency of SARS-CoV-2 infection patients was prolonged (10.7 days vs 7 days), but the hospital length of stay was shortened (15.8 days VS 18 days). The mean latency for SARS-CoV-2 infected patient who came back from Wuhan was the longest (9.2 days), and the average hospital length of stay decreased by patients return from Wuhan, patients exposure to Wuhan population, and patients with no more contact (18.8 days, 15.9 days, 15.2 days). 
medRxiv preprint doi: $h t t p s: / / d o i . o r g / 10.1101 / 2020.03 .16 .20037259$; this version posted March 23, 2020. The copyright holder for this preprint (which was not certified by peer review) is the author/funder, who has granted medRxiv a license to display the preprint in It is made available under a CC-BY-NC-ND 4.0 International license .

Suggesting that the mean latency of SARS-CoV-2 infection may increase with the increase of its transmission chain, and the hospital length of stay for patients with a large number of transmission chains is shortening, indicated that the toxicity of SARS$\mathrm{CoV}-2$ may be reducing in the process of transmission. Moreover, the mean latency of asymptomatic patients was the longest (10.5 days); in contrast, the hospital length of stay was the shortest (14.3 days). These results suggest that SARS-CoV-2 infection may increase the mean latency due to its cryptic nature. However, the hospital length of stay may be shorten due to decreased toxicity during transmission. In addition, the mean latency was long in children and older group(10.8 days, 11.3 days). Overall, the hospital length of stay increases with age. This suggests that in the process of epidemic prevention and control, special attention needs to be paid to children and elderly people. See Table 4 for the detailed data.

Table .4 Developmental outcomes of SARS-CoV-2 infected patients.

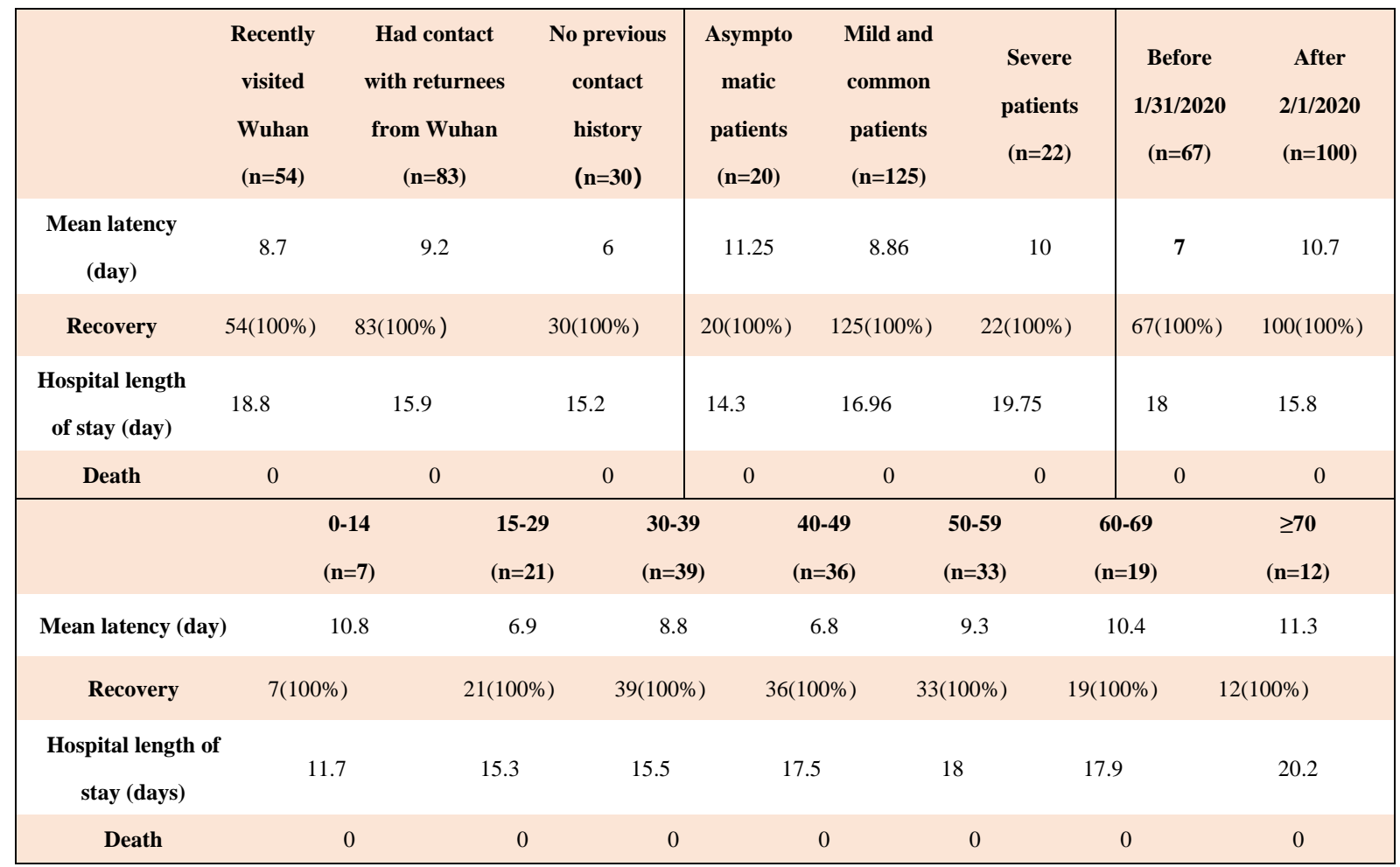

Data are $\mathrm{n}(\%)$ or mean (SD). Patients who have confirmed SARS-CoV-2 infection or are highly suspected of being infected.

Healthy discharges, excluding those who have not yet been discharged or have been reinfected

\section{Recurrence cases}


medRxiv preprint doi: https://doi.org/10.1101/2020.03.16.20037259; this version posted March 23, 2020. The copyright holder for this preprint (which was not certified by peer review) is the author/funder, who has granted medRxiv a license to display the preprint in It is made available under a CC-BY-NC-ND 4.0 International license .

\section{Case A (Recurrence of positive SARS-CoV-2 RNA in COVID-19) :}

A 34-year-old woman was admitted at 1.31(nonsevere), without comoebidities, had been to Wuhan 5 days ago. The CT scan revealed scattered infections in both lungs. White-cell count is $2.69 \times 10^{9}$ cells per L, Neutrophil ratio is $54.3 \%$, Lymphocyte count is $0.96 \times 10^{9}$ cells per $\mathrm{L}$, not admitted to the ICU. Nineteen days later, she was discharged healthy. Upon discharge, the CT scan of her discharge revealed improvement in the absorption of both lung lesions, White-cell count is $5.43 \times 10^{9}$ cells per L, Lymphocyte count is $1.21 \times 10^{9}$ cells per $\mathrm{L}$.

\section{Case B (Recurrence of positive SARS-CoV-2 RNA in COVID-19) :}

A 44-year-old man was admitted at 2.04(nonsevere), without comoebidities, had not contacted Wuhan returnees or traveled to Wuhan. The CT scan revealed scattered infections in both lungs. White-cell count is $2.36 \times 10^{9}$ cells per $\mathrm{L}$, Neutrophil ratio is $60.6 \%$, Lymphocyte count is $0.6 \times 10^{9}$ cells per $\mathrm{L}, \mathrm{CD} 4^{+} \mathrm{T}$ cell count is $196, \mathrm{CD} 8^{+}$ T cell count is $89, \mathrm{CD}^{+} / \mathrm{CD}^{+}$is 2.22 , C-reactive protein is $26.23 \mathrm{mg} / \mathrm{L}$, Procalcitonin is normal, not admitted to the ICU. Eighteen days later, he was discharged healthy. Upon discharge, the CT scan revealed improvement in the absorption of both lung lesions, White-cell count is $5.43 \times 10^{9}$ cells per L, Lymphocyte count is $1.16 \times 10^{9}$ cells per L .

\section{Case C (Recurrence of positive SARS-CoV-2 RNA in COVID-19) :}

A 38-year-old man was admitted at 1.29(severe), without comoebidities, had contact with returnees from Wuhan 4 days ago. The CT scan revealed potential small patchy, flaky ground glass shadows on both lungs. White-cell count is $5.89 \times 10^{9}$ cells per L, Neutrophil ratio is $75.6 \%$, Lymphocyte count is $2.58 \times 10^{9}$ cells per L, CD4 ${ }^{+} \mathrm{T}$ cell count is $252 / \mathrm{ul}, \mathrm{CD}^{+} \mathrm{T}$ cell count is $305 / \mathrm{ul}, \mathrm{CD}^{+} / \mathrm{CD}^{+}$is 0.83 , C-reactive protein is $71.45 \mathrm{mg} / \mathrm{L}$, Procalcitonin is $0.073 \mathrm{ng} / \mathrm{ml}$, not admitted to the ICU. Twentynine days later, he was discharged healthy. Upon discharge, the CT scan revealed the lungs were scattered in stellate, patchy, grid-like ground glass stoves, and cord shadows. White-cell count is $5.77 \times 10^{9}$ cells per L, Lymphocyte count is $1.55 \times 10^{9}$ cells per $\mathrm{L}, \mathrm{CD}^{+} \quad \mathrm{T}$ cell count is $299 / \mathrm{ul}, \mathrm{CD}^{+} \quad \mathrm{T}$ cell count is $264 / \mathrm{ul}, \mathrm{CD}^{+} / \mathrm{CD}^{+}$is 0.83 . 


\section{Discussion}

Chongqing currently has a severe Covid-19 rate of $13.17 \%$ of the 167 patients and no one died. Of the 22 severe Covid-19 patients, 13 (59\%) had a history of travel in Wuhan; and of the 167 SARS-CoV-2 infected patients, $54(32.33 \%)$ had a history of travel in Wuhan. Therefore, Chongqing 's epidemic situation presents typical characteristics of imported cases. The clinical characteristics, radiologic and laboratory indexes and clinical outcomes of these patients with severe Covid-19 are consistent with previous research reports, and only 3 patients (13.64\%) had comorbidities of liver dysfunction, which was lower than the previously reported complication rate of $25.43 \%{ }^{9}$.

WHO has positioned SARS-CoV-2 as a global pandemic, and asymptomatic patients with SARS-CoV-2 infection gradually appear ${ }^{3}$. A recent research report pointed out that a small number of asymptomatic patients with SARS-CoV-2 infection were observed in the imported population from Wuhan ${ }^{10}$. Our results show that 2 out of 54 imported cases are asymptomatic patients in Chongqing, accounted for 3.7\%. The proportion of asymptomatic patients among people infected with SARS-CoV-2 due to contact with imported populations was higher, reaching 18.1\%. Although SARS-CoV2 infection has been reported in children aged 0-14 years ${ }^{11}$, we found 2 children were asymptomatic patients with SARS-CoV-2 infection for the first time, accounting for $28.6 \%$ of infected children. 3 cases of asymptomatic SARS-CoV-2 infection in elderly group, accounting for $25 \%$ of the infections in this age group. The vast majority $(66.67 \%)$ of asymptomatic patients over 70 years of age are accompanied by imaging changes, indicating that this part of the population can be screened by imaging studies. In children and young adults with asymptomatic SARS-CoV-2 infection, although there are changes such as bronchial thickening, there are not many typical clinical changes. As the epidemic develops, the proportion of asymptomatic patients is getting higher and higher (up to $19 \%$ in the onset after February $1^{\text {st }}, 2020$ ). The mean latency of asymptomatic patients with SARS-CoV-2 infection was prolonged (10.5 days), but the hospital length of stay was shortened (14.3 days). 
All countries have adopted isolation measures for imported populations from areas or countries with severe SARS-CoV-2 infection, and treated patients with symptoms who have a history of contact with this imported population ${ }^{1}$. However, a large number of asymptomatic patients with contact history with imported cases failed to be included in the focus surveillance. Our study shows for the first time that asymptomatic patients with SARS-CoV-2 infection have a contact history with imported case account for a large proportion. Therefore, the next stage of SARS-CoV-2 prevention and control needs to focus on the screening of asymptomatic patients in the community with a history of contact with the imported population, especially for children and the elderly. Promoting the worldwide prevention and control of SARS-CoV-2.

Limitations of this study: (1) Because some SARS-CoV-2 infected patients have been discharged from hospitals, and the early epidemic situation is severe, medical workers are devoted to fighting the epidemic, resulting in the loss of some patients' files. (2) 167 Case data we used were from the Chongqing Public Health Medical Center, and the number of asymptomatic infections is 20 , which is relatively small. More case data of asymptomatic patients are needed to confirm our results. (3) Due to the huge workload of medical workers, patients with pneumonia infected by virus complex bacteria are not distinguished. (4) Our data is artificially calculated and not automatically generated by the system, so it has a certain degree of subjectivity.

\section{Contributors}

Yang Tao, Panke Cheng and Wen Chen collected the epidemiological and clinical data and drafted the manuscript. Peng Wan, Yaokai Chen, Guodan Yuan, Junjie Chen collected and summarised all data. Da Huo, Ge Guan, Dayu Sun, Ju Tan and Guanyuan Yang draw figures and tables. Weng Zeng and Chuhong Zhu designed the clinical study, analyzed all data and revised the final manuscript.

\section{Declaration of interests}

We declare no competing interests. 
medRxiv preprint doi: https://doi.org/10.1101/2020.03.16.20037259; this version posted March 23, 2020. The copyright holder for this

preprint (which was not certified by peer review) is the author/funder, who has granted medRxiv a license to display the preprint in

It is made available under a CC-BY-NC-ND 4.0 International license .

\section{Data sharing}

After publication, the data will be made available to others on reasonable requests to the corresponding author. A proposal with detailed description of study objectives and statistical analysis plan will be needed for evaluation of the reasonability of requests. Additional materials might also be required during the process of evaluation. Deidentified participant data will be provided after approval from the corresponding author and Chongqing Public Health Medical Center .

\section{Acknowledgments}

We thank all patients and their families involved in the study. We thank all doctors and nurses in Chongqing Public Health Medical Center. This work was supported by the National Key Research and Development Program (No.2016YFC1101100) and National Science Fund for Distinguished Young Scholars (No. 31625011).

\section{Reference}

1. World Health Organization. Coronavirus disease (COVID-19) outbreak (https://www.who.int. opens in new tab).

2. National Health Commission of the People's Republic of China home page (http://www.nhc.gov.cn. opens in new tab).

3. Du Z, Xu X, Wu Y, et al. Serial interval of COVID-19 from publicly reported confirmed cases. Emerg Infect Dis. 2020. https : //doi.org/10.3201/eid2607.200357, DOI: $10.3201 /$ eid2606.200357

4. Home Page of Wuhan Municipal Health Commission, Hubei Province, China (http://wjw.wuhan.gov.cn/)

5. Home Page of Chongqing Health Committee, China (http://wsjkw.cq.gov.cn/)

6. World Health Organization. Clinical management of severe acute respiratory infection when novel coronavirus (2019-nCoV) infection is suspected: interim guidance. January 28, 2020 (https://www.who.int/docs/default-source/coronaviruse/clinical-management-of-novelcov.pdf. opens in new tab).

7. Metlay JP, Waterer GW, Long AC, et al. Diagnosis and treatment of adults with community- 
medRxiv preprint doi: https://doi.org/10.1101/2020.03.16.20037259; this version posted March 23, 2020. The copyright holder for this preprint (which was not certified by peer review) is the author/funder, who has granted medRxiv a license to display the preprint in It is made available under a CC-BY-NC-ND 4.0 International license .

acquired pneumonia: an official clinical practice guideline of the American Thoracic Society and Infectious Disease Society of America. Am J Respir Crit Care Med 2019;200(7):e45-e67.

8. World Health Organization. Coronavirus disease (COVID-19) technical guidance: laboratory testing for 2019-nCoV in humans (https://www.who.int/emergencies/diseases/novelcoronavirus-2019/technical-guidance/laboratory-guidance. opens in new tab).

9. Guan WJ, Ni ZY, Hu Y, et al. Clinical Characteristics of Coronavirus Disease 2019 in China. N Engl J Med. DOI: 10.1056/NEJMoa2002032

10. Oon-Tek Ng, Kalisvar Marimuthu, Po-Ying Chia, et al. SARS-CoV-2 Infection among Travelers Returning from Wuhan, China. N Engl J Med. DOI: 10.1056/NEJMc2003100

11. Weiyong Liu, Qi Zhang, Junbo Chen, et al. Detection of Covid-19 in Children in Early January 2020 in Wuhan, China. N Engl J Med. DOI: 10.1056/NEJMc2003717

12. World Health Organization. Coronavirus disease (COVID-2019) situation reports (https://www.who.int/emergencies/diseases/novel-coronavirus-2019/situation-reports/). 
medRxiv preprint doi: https://doi.org/10.1101/2020.03.16.20037259; this version posted March 23, 2020. The copyright holder for this preprint (which was not certified by peer review) is the author/funder, who has granted medRxiv a license to display the preprint in It is made available under a CC-BY-NC-ND 4.0 International license .

\section{Support information}

Table .S1 Variable of mild and common patients at different ages

\begin{tabular}{|c|c|c|c|c|c|c|c|}
\hline & $0-14(n=5)$ & $15-29(n=19)$ & $30-39(n=28)$ & $40-49(n=30)$ & $50-59(n=26)$ & $60-69(n=13)$ & $\geq 70(n=4)$ \\
\hline $\begin{array}{l}\text { All patients before } \\
\qquad \begin{array}{c}1 / 31 / 2020 \\
\end{array}\end{array}$ & $2(40 \%)$ & $11(57.9 \%)$ & $18(64.3 \%)$ & $6(20 \%)$ & $9(34.6 \%)$ & $5(38.5 \%)$ & $1(25 \%)$ \\
\hline \multicolumn{8}{|l|}{ Exposure history } \\
\hline Recently visited Wuhan & $1(20 \%)$ & $6(31.6 \%)$ & $16(57.1 \%)$ & $5(16.7 \%)$ & $8(30.8 \%)$ & $4(30.8 \%)$ & $1(25 \%)$ \\
\hline $\begin{array}{c}\text { Contact with Wuhan } \\
\text { residents }\end{array}$ & $4(80 \%)$ & $7(36.8 \%)$ & $8(28.6 \%)$ & $18(60 \%)$ & $7(26.9 \%)$ & $9(69.2 \%)$ & $3(75 \%)$ \\
\hline Smoking history & 0 & $1(5.3 \%)$ & $5(17.9 \%)$ & $4(13.3 \%)$ & $2(7.7 \%)$ & $2(15.4 \%)$ & 0 \\
\hline Mean latency (day) & 11.7 & 6.57 & 7.2 & 6.3 & 9.6 & 10.4 & 10.25 \\
\hline \multicolumn{8}{|l|}{ Clinical symptoms } \\
\hline Fever & $1(20 \%)$ & $13(68.4 \%)$ & $21(75 \%)$ & $14(46.7 \%)$ & $15(57.7 \%)$ & $6(46.2 \%)$ & $2(50 \%)$ \\
\hline Cough & $5(100 \%)$ & $12(63.2 \%)$ & $20(71.4 \%)$ & $22(73.3 \%)$ & $14(53.8 \%)$ & $10(76.9 \%)$ & $3(75 \%)$ \\
\hline Shortness of breath & 0 & $1(5.3 \%)$ & $7(25 \%)$ & $2(6.7 \%)$ & $5(19.2 \%)$ & $3(23.1 \%)$ & $1(25 \%)$ \\
\hline Fatigue & 0 & $2(19.5 \%)$ & $7(25 \%)$ & $7(23.3 \%)$ & $5(19.2 \%)$ & $5(38.5 \%)$ & 0 \\
\hline \multicolumn{8}{|l|}{ Comorbidities } \\
\hline ARDS & & & 0 & 0 & 0 & 0 & 0 \\
\hline Acute kidney injury & 0 & 0 & 0 & 0 & 0 & 0 & 0 \\
\hline Myocardial injury & 0 & 0 & 0 & 0 & 0 & 0 & 0 \\
\hline Liver dysfunction & 0 & $1(5.3 \%)$ & $1(3.6 \%)$ & $2(6.7 \%)$ & $1(3.8 \%)$ & $1(7.7 \%)$ & 0 \\
\hline Urinary infection & 0 & 0 & 0 & 0 & 0 & 0 & 0 \\
\hline Digestive system damage & 0 & 0 & 0 & 0 & 0 & 0 & 0 \\
\hline \multicolumn{8}{|l|}{ Abnormalities on chest $\mathrm{CT}$} \\
\hline Ground-glass opacity & 0 & $6(31.6 \%)$ & $16(57.1 \%)$ & $8(26.7 \%)$ & $8(30.8 \%)$ & $6(46.2 \%)$ & $1(25 \%)$ \\
\hline Bilateral patchy shadowing & 0 & $3(15.8 \%)$ & $4(14.3 \%)$ & $4(13.3 \%)$ & $5(19.2 \%)$ & $5(38.5 \%)$ & $1(25 \%)$ \\
\hline No obvious abnormalities & $1(20 \%)$ & $2(10.5 \%)$ & 0 & 0 & 0 & 0 & 0 \\
\hline \multicolumn{8}{|l|}{ Laboratory findings } \\
\hline White-cell count Median & 6.62 & 4.36 & 4.31 & 5.01 & 5.25 & 5.46 & 4.03 \\
\hline (IQR) & $(4.14-9.1)$ & $(2.7-9.67)$ & $(2.62-18.72)$ & $(2.36-10.53)$ & $(2.99-8.79)$ & $(2.24-6.93)$ & $(3.83-9.06)$ \\
\hline Neutrophil Percentage & $48.85 \%$ & $43.97 \%$ & $52.25 \%$ & $61.79 \%$ & $75.6 \%$ & $69.80 \%$ & $72.3 \%$ \\
\hline median(IQR) & $(41.50-56.20 \%)$ & $(19.15-61.9)$ & $(36.86 \%-89.2 \%)$ & $(47.62 \%-92.12 \%)$ & $(63.3-78.5 \%)$ & $(36.7-79.9 \%)$ & $(58.7-86 \%)$ \\
\hline Lymphocyte count Median & 2.2 & 1.605 & 1.32 & 1.05 & 1.05 & 1.13 & 0.8 \\
\hline (IQR) & $(1.2-3.2)$ & $(0.95-3.17)$ & $(0.69-2.26)$ & $(0.6-2.32)$ & $(0.41-2.31)$ & $(0.64-2.24)$ & $(0.78-1.19)$ \\
\hline \multirow{2}{*}{$\mathrm{T}$ cell detection } & 3209 & 1086 & 867.4 & 815 & 765 & 873.4 & 548 \\
\hline & (3209) & $(656-2250)$ & $(406-1527)$ & $(369-1620)$ & $(350-1374)$ & $(373-1066)$ & $(473-588)$ \\
\hline \multirow{2}{*}{ CD4+ T cell count } & 869 & 459 & 419.4 & 430.5 & 423.7 & 495.3 & 308.3 \\
\hline & $(347-1770)$ & $(229-1209)$ & $(174-886)$ & $(185-804)$ & $(191-774)$ & $(205-848)$ & $(249-371)$ \\
\hline \multirow{2}{*}{$\mathrm{CD} 8+\mathrm{T}$ cell count } & 790 & 526 & 337 & 287.6 & 278.3 & 303 & 169.5 \\
\hline & $(667-1439)$ & $(231-991)$ & $(158-628)$ & $(89-765)$ & $(54-568)$ & $(121-517)$ & $(152-187)$ \\
\hline $\mathrm{CD} 4+/ \mathrm{CD} 8+$ & $1.1(0.52-1.23)$ & 0.965 & 1.36 & 1.60 & 2.02 & 1.67 & 1.99 \\
\hline
\end{tabular}


medRxiv preprint doi: https://doi.org/10.1101/2020.03.16.20037259; this version posted March 23, 2020. The copyright holder for this preprint (which was not certified by peer review) is the author/funder, who has granted medRxiv a license to display the preprint in It is made available under a CC-BY-NC-ND 4.0 International license

\begin{tabular}{|c|c|c|c|c|c|c|c|}
\hline & & $(0.54-2.46)$ & $(0.79-1.94)$ & $(0.86-2.84)$ & $(0.54-3.73)$ & $(1.25-1.99)$ & $(1.98-2)$ \\
\hline Platelet count, Median & 241 & 147 & 186 & 140.5 & 173 & 233 & 200 \\
\hline (IQR) & (241) & $(105-341)$ & $(79-455)$ & $(94-350)$ & $(67-501)$ & $(68-331)$ & $(158-424)$ \\
\hline $\begin{array}{l}\text { Elevated C-reactive protein } \\
\qquad(>10 \mathrm{mg} / \mathrm{L})\end{array}$ & $1(20 \%)$ & $1(5.3 \%)$ & $9(32.1 \%)$ & $11(36.7 \%)$ & $5(19.2 \%)$ & $4(30.8 \%)$ & $2(50 \%)$ \\
\hline $\begin{array}{l}\text { Elevated Procalcitonin } \\
\qquad(>0.5 \mathrm{ng} / \mathrm{ml})\end{array}$ & 0 & 0 & $2(7.1 \%)$ & $3(10 \%)$ & $2(7.7 \%)$ & $4(30.8 \%)$ & 0 \\
\hline \multicolumn{8}{|l|}{ Clinical outcome } \\
\hline Recovery & $5(100 \%)$ & $19(100 \%)$ & $28(100 \%)$ & $30(100 \%)$ & $26(100 \%)$ & $13(100 \%)$ & $4(100 \%)$ \\
\hline $\begin{array}{l}\text { Hospital length of stay } \\
\text { (days) }\end{array}$ & 9.8 & 15.83 & 15.07 & 19.55 & 17.25 & 19.25 & 22 \\
\hline Death & 0 & 0 & 0 & 0 & 0 & 0 & 0 \\
\hline
\end{tabular}

Data are median (IQR), n (\%) or mean (SD). Some patients lack certain tests, or some patients' mean latency is unknown. White blood cell count $\left(\times 10^{9}\right.$ cells per $\left.\mathrm{L}\right)$. Lymphocyte count $\left(\times 10^{9}\right.$ cells per L) . Platelet count, $\times 10^{9}$ per L. ARDS $=$ acute respiratory distress syndrome. Patients means people who have confirmed SARS-CoV-2 infection or are highly suspected of being infected. 